\title{
PENGOLAHAN AIR LIMBAH DOMESTIK DENGAN ANOKSIK-AEROBIK MOVING BED BIOFILM REACTOR (STUDI KASUS: PENYISIHAN AMONIA DAN KARBON DALAM AIR LIMBAH DOMESTIK)
}

Domestic Wastewater Treatment With Anoxic-Aerobic Moving Bed Biofilm Reactor (Case Study: Ammonium And Carbon Removal In Domestic Wastewater)

Oleh :

Berliana C. Ningtias ${ }^{1}$, Setyo S. Moersidik ${ }^{1}$, Cindy R. Priadi ${ }^{1}$, dan Nusa Idaman Said ${ }^{2}$

${ }^{1}$ Departemen Teknik Sipil, Fakultas Teknik, Universitas Indonesia, Kampus UI Depok,

${ }^{2}$ Peneliti Utama Kelompok Teknologi Pengelolaan Air Bersih dan Limbah

Pusat Teknologi Lingkungan, BPPT

Jl. M.H. Thamrin No. 8 Gd. II Lt. 18 Jakarta 10340

\begin{abstract}
Abstrak
Air limbah domestik yang mengandung konsentrasi karbon dan amonia yang tinggi dapat diolah dengan proses Moving Bed Biofilm (MBB) yang merupakan biological hybrid antara pertumbuhan melekat dengan tersuspensi. Penelitian ini bertujuan mengetahui persentase penyisihan karbon dan amonia, serta menentukan waktu tinggal hidrolis optimal. Penelitian ini merupakan skala laboratorium dengan mengkombinasikan reaktor anoksik dan aerobik MBB. Penelitian dimulai dengan proses seeding selama 4 minggu dilanjutkan dengan pengolahan dengan variasi waktu tinggal hidrolis. Berdasarkan hasil penelitian ini, persentase penyisihan COD dengan waktu tinggal hidrolis 12, 16 dan 20 jam adalah 75,7\%; 83,7\%; dan 91,0\% dan penyisihan amonia adalah 79,4\%; 91,0\%; dan 92,3\%. Waktu tinggal hidrolis yang optimal menurunkan konsentrasi COD dan amonia air limbah menggunakan proses anoksik aerobik MBB adalah 20 jam. Pengolahan dengan biological hybrid ini dapat dijadikan salah satu alternatif dalam menyisihkan konsentrasi karbon dan amonia dalam air limbah domestik.
\end{abstract}

Kata Kunci : air limbah domestik, penyisihan amonia, penyisihan karbon organik, moving bed biofilm reactor

\begin{abstract}
Domestic wastewater contains high organic carbon and ammonium concentration which can be treated by moving bed biofilm process. It is a biologycal hybrid between attached and suspended growth process. The purposes of this research were to determine the removal percentage of organic carbon and ammonium concentration in domestic wastewater, and to investigate optimum hydraulic residence time. Experiment was carried out in a laboratory scale to study the combine anoxic and an aerobic reactor condition. The treatment process is preceeded by a 4-week seeding process continued with variation of hydraulic residence time. Based on these results, the removal percentage of COD for each hydraulic residence time of 12, 16, and 20 hours were 75,7\%; $83,7 \%$; and $91,0 \%$, the removal percentage of ammonium were $79,4 \% ; 91,0 \%$; and $92,3 \%$. The optimum hydraulic residence time in removing organic carbon and ammonium concentration domestic wastewater using anoxic aerobic MBB is 20 hours. This biological hybrid treatment can be an alternative to remove organic carbon and ammonium in domestic wastewater.
\end{abstract}

Keyword: domestic wastewater, ammonium removal, organic carbon removal, moving bed biofilm reactor 


\section{PENDAHULUAN}

Air limbah merupakan air sisa yang sudah tidak terpakai sebagai hasil dari kegiatan manusia sehari-hari, yang kehadirannya pada titik waktu, konsentrasi, dan tempat tertentu tidak dikehendaki oleh lingkungan karena kandungannya yang bersifat menurunkan kualitas komponen lingkungan bila tidak dilakukan penanganan dan pengolahan. Berdasarkan sumbernya, timbulan air limbah domestik berasal dari kegiatan domestik di daerah pemukiman, perkantoran, dan komersial. Timbulan air limbah domestik terkait dengan adanya indikasi peningkatan penggunaan air di perkotaan dan pemusatan kegiatan permukiman di perkotaan. Laporan Kementrian Lingkungan Hidup (2013) menuturkan bahwa data dari kualitas ketiga belas badan air penerima yang melewati wilayah Jakarta (termasuk sungai Ciliwung) menunjukkan telah terjadi penurunan kualitas air permukaan sebagian besar diakibatkan dari air limbah domestik sekitar $80 \%$. Beban polutan organik yang terkandung dalam air limbah domestik rumah tangga dan perkantoran lebih besar, yaitu sekitar $84 \%$, sedangkan perindustrian memberikan kontribusi sebesar $16 \%$. Dengan demikian, air limbah domestik, baik dari permukiman maupun perkantoran, berkontribusi lebih besar dalam kondisi pencemaran air di wilayah Jakarta.

Berdasarkan permasalahan umum di atas, penanganan dan pengolahan air limbah domestik menjadi prioritas dalam mencegah pencemaran air lebih lanjut akibat peningkatan timbulan air limbah domestik. Tindakan penanganan tersebut dapat berupa pelaksanaan prinsip 3R (Reuse, Reduce, dan Recycle) dari sumbernya, sedangkan tindakan pengolahan adalah aplikasi dari penguraian beban polutan organik air limbah dan konversi bentuknya yang komplek menjadi bentuk yang lebih stabil dan sederhana, sehingga aman ketika dibuang ke lingkungan. Jenis pengolahan air limbah yang umum digunakan adalah pengolahan dengan proses lumpur aktif, reaktor biologis putar, dan Trickling Filter, di mana kesemuanya sering diaplikasikan pada sebagian besar permukiman dan institusi, tetapi yang masih menjadi perhatian adalah kurang efektifnya aplikasi pengolahan beserta pemilihan yang tepat jenis teknologi pengolahan air limbah yang dilakukan, memerlukan lahan luas untuk memisahkan lumpur dan cairan olahan, tidak tahan terhadap fluktuasi debit limbah yang besar, fungsi aerasi yang kurang baik, dan penyumbatan pada media biofilter. Hal yang menunjukkan pengolahan air limbah tersebut kurang efektif adalah masih terdapatnya konsentrasi beban pencemar yang berada melebihi baku mutu efluen bagi air limbah domestik yang ditetapkan, terutama konsentrasi Amonia. Kandungan Amonia air limbah domestik umumnya berasal dari urinasi dan dekomposisi kotoran organik yang dihasilkan dari pembusukan bahan organik ekskreta manusia. Jika mengacu pada peraturan sebelumnya, (Kepmen LH No. 112/2003) tidak dicantumkan ketentuan tentang baku mutu konsentrasi Amonia, maka berdasarkan permasalahan lingkungan akibat Amonia yang berlebih, tahun 2005 baku mutu Amonia diperketat menjadi $10 \mathrm{mg} /$ liter (dalam PerGub DKI Jakarta No. 122/2005 Tentang Pengolahan Limbah Domestik di Propinsi DKI Jakarta), di mana besarnya kandungan amonia pada air limbah domestik adalah 40-250 $\mathrm{mg} /$ liter (BPPT, 2010).

Dalam air limbah, mikroorganisme akan mengonversi amonia tersebut dari bentuk amonium $\left(\mathrm{NH}_{4}-\mathrm{N}\right)$ menjadi ion nitrat $\left(\mathrm{NO}_{3}-\mathrm{N}\right)$ dengan mengonsumsi sejumlah besar oksigen terlarut. Pengolahan air limbah yang sering digunakan untuk permasalahan besarnya konsentrasi Amonia air limbah domestik adalah pengolahan secara biologis, yaitu mengolah limbah pada sebuah sistem dengan waktu tinggal tertentu, kondisi tertentu, dan konsentrasi polutan tertentu, sehingga aktivitas mikroorganisme yang hidup secara alami dalam air limbah tersebut dapat mengoksidasi senyawa polutan yang ada dalam air limbah. Pengolahan air limbah secara biologis dibagi menjadi dua, yaitu proses pertumbuhan terlekat dan tersuspensi, di mana menggunakan konsep pertumbuhan mikroorganisme yang berbeda. Efisiensi penyisihan konsentrasi polutan dalam proses pertumbuhan tersuspensi, untuk konsentrasi BOD dan CODmasing-masing adalah $80-85 \%$, sedangkan penyisihan Amonium 8$15 \%$. Pertumbuhan terlekat persentase penyisihan si BOD dan COD air limbah lebih kecil dibandingkan tersuspensi (masing-masing 60-80\%) dan konsentrasi Amonianya 8-15\% (Qasim,1985). Dengan demikian, proses pengolahan air limbah secara pertumbuhan biologis terlekat dan tersuspensi masih belum menyelesaikan permasalahan kelebihan konsentrasi Amonia dalam air limbah, sehingga diperlukan adanya kombinasi proses pengolahan untuk meningkatkan efisiensi penyisihan (Odegaard dan Rusten, 1994). Konsep pengolahan Moving Bed Biofilm Reactor (MBBR) menggunakan konsep kombinasi proses pertumbuhan terlekat dan tersuspensi, membuat mikroorganisme tumbuh melekat pada media isian yang dibuat melayanglayang di dalam air limbah sistem dan umumnya kondisi yang terbentuk adalah nitrifikasi dan denitrifikasi secara parsial. Dengan demikian, anoksikaerobik Moving Bed Biofilm cukup efektif dalam menyisihkan konsentrasi polutan dalam air limbah dengan karakteristik tingginya konsentrasi Amonia. Berdasarkan uraian permasalahan di atas, penelitian ini melakukan percobaan skala laboratorium dengan mengalirkan air limbah domestik secara kontinyu dalam kondisi anoksik dilanjutkan dengan kondisi 
aerobik Moving Bed Biofilm, yang diharapkan adanya persentase penyisihan konsentrasi polutan (terutama COD dan Amonia) yang signifikan.

\section{TINJAUAN TEORITIS}

\subsection{Proses Pengolahan Air Limbah Domestik Secara Biologis}

Proses pengolahan air limbah secara biologis merupakan proses pengolahan yang memanfaatkan aktivitas metabolisme mikroorganisme dalam mengoksidasi bahan pencemar yang terkandung dalam air limbah. Aktivitas metabolisme mikroorganisme dalam air limbah akan menghasilkan enzim yang mampu mengkatalisasi proses degradasi sehingga proses oksidasi menjadi lebih cepat. Berdasarkan Qasim (1985), yang diperlukan secara mendasar pada pengolahan biologis adalah:

a. Adanya populasi mikroorganisme

b. Kotak yang baik antara mikrooganisme dengan air limbah.

c. Ketersediaan oksigen dan nutrisi

Pemeliharaan kondisi operasional pengolahan (seperti suhu, $\mathrm{pH}$, karbon ekstenal, dan lain-lain). Mekanisme transformasi kandungan organik dan anorganik dilakukan dengan memanfaatkan aktivitas metabolisme mikroorganisme sebagai pengurai. Hasil pengolahan air limbah dari unit biologis adalah berupa air olahan dengan kualitas biologisnya tidak berbahaya dan lumpur biomassa yang akan diresirkulasikan ke bagian unit biologis kembali dan sisa lumpur (lumpur dengan umur yang lebih lama) akan dialirkan menuju pengolahan lumpur. Tujuan adanya pengolahan air limbah secara biologis adalah :

a. Menghilangkan nonsettleable colliodal solids dalam air limbah.

b. Menstabilkan kandungan organik dan anorganik yang terlarut pada air limbah dengan cara mengubah kandungan pencemar menjadi partikel biosolid dan gas (Horan, 1991).

c. Membersihkan zat-zat organik atau mengubah bentuk (transformasi) zar-zat organik menjadi bentuk-bentuk yang kurang berbahaya.

d. Menggunakan kembali zat-zat organik yang terdapat dalam air limbah seperti gas metana atau residu-residu pengolahan.

e. Berkaitan dengan subproses biokimia dengan menghilangkan Carbonaerous Biochemical Oxygen Demand (CBOD), nutrien dalam air limbah.

Untuk mewujudkan tercapainya kinerja penyisihan bahan organik dan inorganik dalam air limbah yang dilakukan dengan pengolahan biologis, menurut Sarwanto (1995) terdapat pendekatan ialah konsentrasi mikroorganisme dalam reaktor setinggi mungkin, kontak antara mikroorganisme dengan air limbah yang mencukupi, kontak reaksi untuk mikroorganisme terpenuhi, dan cara pemisahan mikroorganisme dari efluen mudah dilaksanakan. Berikut ini stoikiometri penyisihan substrat oleh sel mikroorganisme:

Oksidasi oleh sel mikroorganisme:

$\mathrm{CHONS}+\mathrm{O}_{2}+$ bakteri $\rightarrow \mathrm{CO}_{2}+\mathrm{NH}_{3}+$ Produk akhir + Energi

Sintesis materi oleh sel mikroorganisme:

$\mathrm{CHONS}+\mathrm{O}_{2}+$ bakteri + Energi $\rightarrow \mathrm{C}_{5} \mathrm{H}_{7} \mathrm{NO}_{2}$

Respirasi endogen dalam sel mikroorganisme:

$\mathrm{C}_{5} \mathrm{H}_{7} \mathrm{NO}_{2}+5 \mathrm{O}_{2} \rightarrow 5 \mathrm{CO}_{2}+2 \mathrm{H}_{2} \mathrm{O}+\mathrm{NH}_{3}+$ Energi (3)

\subsection{Proses Nitrifikasi dan Denitrifikasi Air Limbah Domestik}

Nitrifikasi merupakan konversi nitrogen amonia $\left(\mathrm{NH}_{4}{ }^{+}-\mathrm{N}\right)$ menjadi nitrat $\left(\mathrm{NO}_{3}{ }^{+}-\mathrm{N}\right)$ yang dilakukan oleh bakteri heterotrof maupun autotrof. Bakteri autotrof pada dasarnya menggunakan materi anorganik dan gas $\mathrm{CO}_{2}$ atau $\mathrm{HCO}_{3}{ }^{-}$sebagai sumber karbon tunggal. Senyawa karbondioksida yang dibutuhkan oleh bakteri autotrof berasal dari aktivitas degradasi bakteri heterotrof dalam menguraikan karbon, di mana bakteri heterotrof membutuhkan karbon dalam bentuk yang relatif kompleks/senyawa organik untuk sintesis sel (Benefield dan Randall, 1980). Genus bakteri yang melaksanakan proses nitrifikasi adalah Nitrosomonas dan Nitrobacter. Bakteri Nitrosomonas mampu mengoksidasi $\left(\mathrm{NH}_{4}{ }^{+} \mathrm{N}\right)$ menjadi nitrit melalui tahapan sebagai berikut:

$$
\begin{aligned}
& \mathrm{NH}_{4}{ }^{+}+\text {Energi } \rightarrow\left(\mathrm{NH}_{2}\right) \rightarrow \mathrm{NH}_{2} \mathrm{OH} \rightarrow(\mathrm{NHOH}) \rightarrow \mathrm{NOH} \\
& \rightarrow \mathrm{NO} \rightarrow \mathrm{NO}_{2}
\end{aligned}
$$

Sedangkan bakteri Nitrobacter akan membantu proses oksidasi nitrit menjadi nitrat dalam persamaan berikut:

$\mathrm{NO}_{2}{ }^{-}+\mathrm{H}_{2} \mathrm{O} \rightarrow \mathrm{NO}_{3}{ }^{-}+2 \mathrm{H}^{+}+2 \mathrm{e}^{-}$

Berdasarkan Gujer dan Jenkins (1974) dalam Sarwanto (1995), persamaan stoikiometri untuk pertumbuhan bakteri Nitrosomonas dan Nitrobacter adalah sebagai berikut:

- Pertumbuhan Nitrosomonas:

$55 \mathrm{NH}_{4}{ }^{+}+76 \mathrm{O}_{2}+109 \mathrm{HCO}_{3}{ }^{-} \rightarrow \mathrm{C}_{5} \mathrm{H}_{7} \mathrm{NO}_{2}+54$ $\mathrm{NO}_{2}^{-}+57 \mathrm{H}_{2} \mathrm{O}+104 \mathrm{H}_{2} \mathrm{CO}_{3}^{-}$ (6)

- Pertumbuhan Nitrobacter: 
$400 \mathrm{NO}_{2}^{-}+\mathrm{NH}_{4}^{+}+4 \mathrm{H}_{2} \mathrm{CO}_{3}{ }^{-}+\mathrm{HCO}_{3}^{-}+195 \mathrm{O}_{2} \rightarrow$ $\mathrm{C}_{5} \mathrm{H}_{7} \mathrm{NO}_{2}+3 \mathrm{H}_{2} \mathrm{O}+400 \mathrm{NO}_{3}$

Berdasarkan kedua persamaan stoikiometri di atas, dapat ditarik pengertian bahwa:

- Alkalinitas dipergunakan dalam jumlah besar selama proses oksidasi amonium yaitu sebesar $8,64 \mathrm{mg}\left(\mathrm{HCO}_{3}{ }^{-}\right)$per $\mathrm{mg} \quad\left(\mathrm{N}-\mathrm{NH}_{4}{ }^{+}\right)$yang dioksidasi.

- Untuk melakukan oksidasi $1 \mathrm{mg}\left(\mathrm{N}_{-} \mathrm{NH}_{4}{ }^{+}\right)$ menjadi $\left(\mathrm{N}-\mathrm{NO}_{2}{ }^{-}\right)$diperlukan 3,22 mg oksigen untuk melanjutkan proses oksidasi menjadi ( $\mathrm{N}$ $\mathrm{NO}_{3}{ }^{-}$) diperlukan sebesar 1,11 mg oksigen per $\mathrm{mg}\left(\mathrm{N}-\mathrm{NO}_{2}{ }^{-}\right)$sehingga total oksigen yang dibutuhkan untuk mengoksidasi $1 \mathrm{mg}\left(\mathrm{N}-\mathrm{NH}_{4}{ }^{+}\right)$ menjadi $\left(\mathrm{N}-\mathrm{NO}_{3}{ }^{-}\right.$)adalah $4,33 \mathrm{mg}$.

Oleh karena itulah, reaksi oksidasi amonium dalam air limbah dapat mengonsumsi oksigen terlarut dalam jumlah besar sehingga penurunan konsentrasi oksigen terlarut akan mempengaruhi kondisi fisik air limbah seperti $\mathrm{pH}$ lebih asam, warna lebih gelap, alkalinitas rendah, dan sebagainya, sehingga akibat dari adanya proses nitrifikasi akan dilakukan penambahan alkalinitas.

Proses denitrifikasi terjadi setelah kandungan oksigen terlarut dalam air limbah telah dikonsumsi besar oleh proses nitrifikasi (bakteri autotrof) dan timbul ion-ion nitrat yang menggantikan kehadiran amonium dalam air limbah setelah nitrifikasi. Bakteri yang berperan dalam proses denitrifikasi adalah bakteri heterotrof yang mengonsumsi ion nitrat dalam kondisi anoksik dengan mereduksi nitrat menjadi nitrit dan kemudian menjadi gas nitrogen. Pada umumnya dilakukan penambahan sumber karbon untuk menaikkan kecepatan denitrifikasi. Penambahan ini dimaksudkan untuk menjadikan sumber karbon tersebut adalah pendonor elektron. Karbon ini selain ditambahkan, juga terdapat dalam lumpur sisa dari proses nitrifikasi tetapi reaksinya berjalan lebih lambat dari pada proses melalui pemberian makan dengan senyawa kimia murni tersebut, hal ini dikarenakan jumlah organik karbon yang tersedia di lumpur relatif sedikit dan lebih sukar terurai (Sarwanto, 1995).

Reaksi Proses Denitrifikasi

$$
\frac{1}{5} \mathrm{NO}_{3}{ }^{-}+\frac{1}{5}\left\{\mathrm{CH}_{2} \mathrm{O}\right\}+\frac{1}{5} \mathrm{H}^{+} \rightarrow \frac{1}{10} \mathrm{~N}_{2}+\frac{1}{4} \mathrm{CO}_{2}+\frac{1}{20} \mathrm{H}_{2} \mathrm{O}
$$

\subsection{Pengolahan Biologis dengan Kondisi Anoksik- Aerobik Moving Bed Biofilm}

Moving Bed Biofilm ini merupakan pengolahan yang dikembangkan dengan tetap memegang konsep pertumbuhan melekat lumpur aktif dengan konsep penambahan media pembawa mikroorganisme pengurai yang dapat bergerak dalam air limbah. Dalam proses Moving Bed Biofilm ini, biofilm akan terbentuk dengan adanya proses pembenihan air limbah terlebih dahulu untuk kemudian jika telah berada pada kondisi steady state, akan terlihat seluruh permukaan media akan ditutupi oleh mikroorganisme pengurai. Media pembawa tersebut akan tersuspensi dalam gerakan aliran yang konstan dalam reaktor. Pada umumnya, reaktor Moving Bed Biofilm disediakan sieve arrangement pada bagian outlet reaktor guna mencegah media pembawa tersebut keluar dari reaktor akibat adanya gaya dorong aerator dalam reaktor (Mannina dan Viviani, 2009).

Berdasarkan Metcalf dan Eddy (2003); Pastorelli etal.(1999), kelebihan dari proses Moving Bed Biofilm pada pengolahan air limbah adalah:

a. Unit media yang bersifat padat dan pada umumnya terbuat dari bahan plastik dengan ukuran yang kecil.

b. Kapasitas pengolahan meningkat dengan adanya driving energy dari dalam reaktor dan menggunakan efisiensi penggunaan fine bubble.

c. Penyisihan padatan dalam air limbah cukup baik.

d. Karakteristik pengendapan dapat diperbaiki sesuai dengan kebutuhan dan karakteristik (kualitas dan kuantitas) masing-masing jenis air limbah.

e. Operasi pada konsentrasi biomassa tersuspensi yang lebih besar menghasilkan waktu tinggal lumpur biomassa lebih tahan lama. Hal ini disebabkan oleh biomassa yang tumbuh pada media dapat saja memiliki ketebalan yang berbeda-beda di setiap media sesuai dengan kondisi fisik pengoperasian reaktor.Waktu tinggal lumpur biomassa yang lebih lama akan menyebabkan nutrien mikroorganisme yang digunakan untuk resirkulasi lumpur akan semakin banyak dan mencukupi.

f. Tidak memerlukan pencucian ulang secara periodik (periodic backwashing).

g. Mengurangi produksi lumpur dan tidak bermasalah dengan sludge bulking.

\section{METODE PENELITIAN}

\subsection{Jenis Penelitian}

Penelitian ini menggunakan metode eksperimental, di mana dalam pelaksanaannya ditujukan untuk mengetahui hubungan sebab-akibat antar beberapa variabel atau parameter penelitian dengan cara mengendalikan pengaruh variabel lain dan bersifat kuantitatif (bergantung pada informasi numerik dan diasosiasikan dengan analisa statistik), analisis data penelitian didukung dengan melakukan studi literatur, pengamatan, dan pengujian parameter 
pada eksperimental ini. Penelitian bergantung pada proses pelaksanaan eksperimental yang akan mempengaruhi kinerja reaktor dan kualitas parameter uji.

\subsection{Populasi dan Sampel}

Populasi dalam penelitian ini meliputi air limbah domestik yang belum memenuhi baku mutu lingkungan PerGub DKI Jakarta No. 122/2005, di mana berasal dari bak pengumpul saluran pembuangan air toilet gedung Geostech Badan Pengkajian dan Penelitian Teknologi, Kawasan Puspiptek Serpong. Sampel yang diujicobakan adalah sampel sebanyak $300 \mathrm{ml}$ di titik inlet dan outlet dari rangkaian reaktor seperti pada gambar berikut.
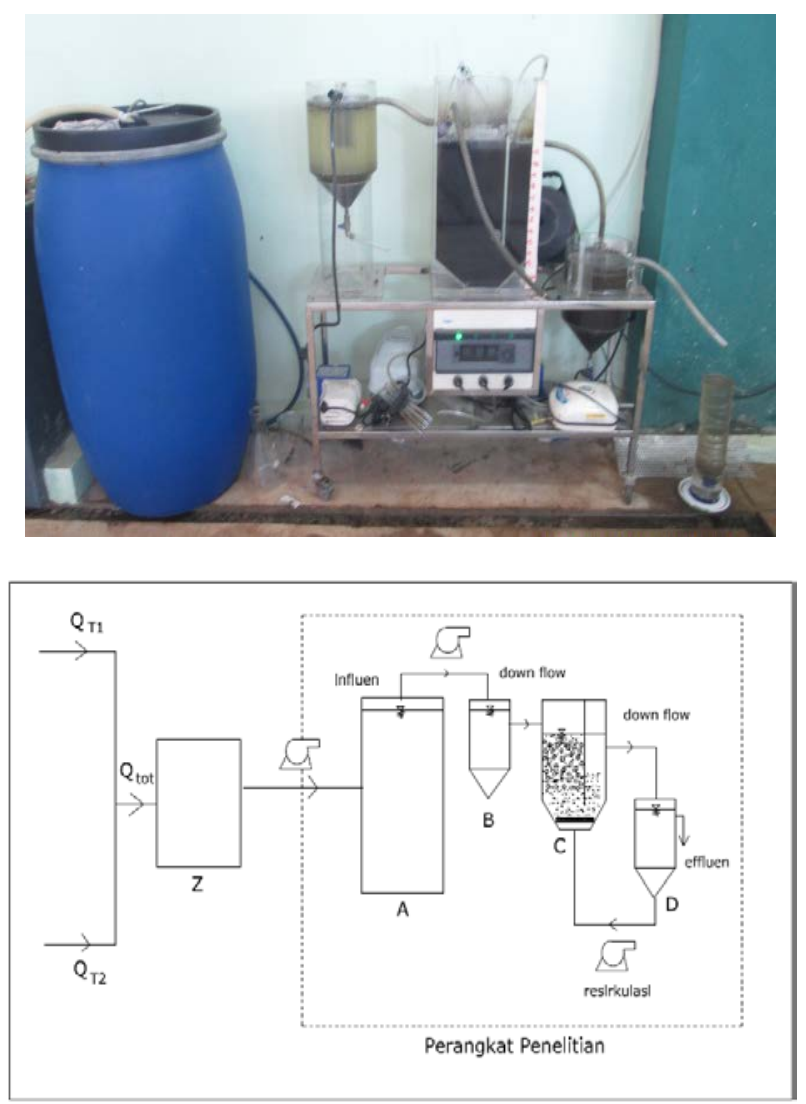

Keterangan Gambar:

Q T1 = Air Limbah Domestik dari Gedung 1

$\mathrm{QT}$ T = Air Limbah Domestik dari Gedung 2

$\mathrm{Q}$ Tot $=$ Air Limbah dari Gedung 1 dan Gedung 2

$\mathrm{d} \quad \mathrm{Z}=$ Bak Penampung Pusat KantorGeosystem Technology BPPT

e $\mathrm{A}=$ Unit Ekualis asi

$\mathrm{f} \quad \mathrm{B}=$ Unit AnoksikMoving Bed Biofilm

g $\mathrm{C}=$ Unit Aerobik Moving Bed Biofilm

$\mathrm{h} \quad \mathrm{D}=$ Unit Pengendapan Akhir (Efluen)

Gambar 1 : Rangkaian Reaktor Penelitian Moving Bed Biofilm

\subsection{Percobaan Pengolahan}

Metode yang digunakan adalah reaktor dijalankan dalam waktu tinggal berbeda dan dilakukan dengan seri, yaitu 12 jam, 8 jam, dan 6 jam. Hal tersebut dilakukan dengan waktu tinggal berbeda agar dapat terlihat hasil penurunan konsentrasi karbon dan amonia yang terefektif dengan kondisi terkontrol, dengan hipotesis literatur penelitian Sya'bani (2012), menunjukkan bahwa waktu tinggal terefektif (terpendek) dalam menurunkan konsentrasi karbon dan amonia adalah 6 jam dengan kondisi reaktor aerobik $20 \%$ filling ratio (volume media terhadap volume reaktor kosong), penyisihan karbon mencapai $91 \%$ dan penyisihan amonia mencapai $89 \%$. Namun, ketika hasil seeding (pembenihan bakteri) di awal pengoperasian reaktor (dalam waktu tinggal 12 jam) menunjukkan hasil yang tidak efektif (tidak efektif di sini, dimaksudkan ketika efisiensi penyisihan COD dan amonia dalam pengolahan ini belum sesuai dengan Baku Mutu Lingkungan yang menjadi acuan penelitian ini), maka langkah selanjutnya yang dapat diambil adalah menambah waktu tinggal menjadi lebih lama dari 12 jam sehingga waktu kontak antara koloni mikroorganisme dan substrat dalam air limbah yang masuk, serta pertumbuhan lapisan biologis pada media dapat optimal (kondisi optimal yang dimaksud adalah kondisi ketika efisiensi penyisihan COD dan amonia telah stabil $\pm 10 \%$ dari kondisi sebelumnya) dan teraklimatisasi sehingga dapat menciptakan proses degradasi yang maksimal.

\subsection{Parameter Pengujian}

Variabel utama yang diujikan adalah $\mathrm{pH}$, Temperatur, konsentrasi oksigen terlarut, BOD, COD, dan $\mathrm{NH}_{4}-\mathrm{N}$. Analisa kualitas sampel air limbah akan dilakukan rutin dan selama air limbah telah dilakukan proses pembenihan dan melewati kondisi steady state, yaitu kondisi di mana konsentrasi organik air limbah (terutama konsentrasi COD) dengan selisih persentase penyisihannya kurang lebih 10\% (Pardede, 1995; Fitriani, 1999). Setelah dilakukan tahap pembenihan air limbah, maka pengoperasian alat dilanjutkan dengan tahap pengumpanan, di mana reaktor telah beroperasi penuh. Pengumpanan ini dilakukan dengan mengalirkan air limbah secara kontinyu juga dengan debit yang telah ditentukan. Setelah kondisi tunak tercapai, maka pengambilan sampel dapat dilakukan.

\section{HASIL PENELITIAN DAN PEMBAHASAN}

Kondisi awal air limbah domestik yang dijadikan sebagai objek penelitian adalah sebagai mana ditunjukkan oleh Tabel 1.

Berdasarkan Tabel 1 karakteristik awal air limbah domestik di atas, dapat terlihat bahwa rasio $\mathrm{BOD}_{5}$ dan COD pada penelitian ini mencapai 0,50 dan 
ratio Amonia dan COD adalah sebesar0,81, dan bila dibandingkan dengan komposisi air limbah pada gedung BPPT Thamrin dalam penelitian Sya'bani (2012), ialah sangat berbeda, di mana ratio $\mathrm{C} / \mathrm{N}$ air limbah pada penelitian ini lebih tinggi dikarenakan konsentrasi amonia yang berlebihan, sedangkan konsentrasi karbon organik tidak begitu tinggi dan juga dapat disebabkan oleh objek air limbah ini diambil bukan dari bak ekualisasi gedung sehingga komposisinya tidak begitu homogen dan ideal. Hal tersebut menyebabkan substrat sebagai nutrien bagi mikroorganisme pengurai membutuhkan nutrien tambahan seperti glukosa monohidrat/sukrosa dan urea untuk mendukung proses pertumbuhan koloni mikroorganisme dalam reaktor. Pada penelitian Sya'bani (2012), karakteristik awal influen memiliki rasio amonia dan COD lebih kecil dibandingkan penelitian ini yaitu 0,31 sehingga komposisinya dapat lebih mudah dan cepat untuk menurunkan konsentrasi amonia dalam air limbahnya. Karakteristik awal air limbah influen proses pengolahan sudah seharusnya diperhatikan rasio $\mathrm{BOD}_{5}$ dan COD serta rasio Amonia dan COD sehingga proses pengolahan air limbah dapat difokuskan untuk menyisihkan jenis parameter yang terlihat bermasalah / tidak memenuhi baku mutu lingkungan yang telah ditetapkan.

Tabel 1 : Karakteristik Air Limbah Domestik Gedung BPPT Serpong

\begin{tabular}{|c|c|c|c|}
\hline Parameter & Satuan & Nilai & BML \\
\hline COD & $\mathrm{mg} / \mathrm{L}$ & 120,8 & 80 \\
\hline BOD $_{5}$ & $\mathrm{mg} / \mathrm{L}$ & 60,5 & 100 \\
\hline $\mathrm{DO}$ & $\mathrm{mg} / \mathrm{L}$ & 3,2 & $4-8$ \\
\hline Amonia & $\mathrm{mg} / \mathrm{L}$ & 98,43 & 10 \\
\hline $\mathrm{pH}$ & & 8 & $6-9$ \\
\hline Suhu & Celcius & 30,5 & $29-31$ \\
\hline
\end{tabular}

Sumber: Hasil Pengolahan Peneliti, 2014

Proses pengolahan dengan model Moving Bed Biofilm yang diaplikasikan ini termasuk proses pengolahan air limbah yang mengandalkan kondisi degradasi mikroorganisme berbentuk flok dan biofilm. Mikroba berbentuk flok memiliki massa jenis yang lebih kecil dibandingkan dengan larutan mediumnya dalam reaktor sehingga flok lebih dominan berada dalam kondisi tersuspensi dalam air limbah/mediumnya. Sedangkan mikroba yang berbentuk biofilm merupakan sekumpulan/komunitas bakteri yang membentuk koloni kecil, terdiri dari sel-sel mikroorganisme yang terbentuk dari adanya nutrien yang cukup, terikat, melekat, dan berhubungan satu dengan yang lainnya pada sebuah permukaan. Tidak hanya bakteri yang terkandung dalam biofilm tetapi ada jenis mikroorganisme lainnya (fungi, algae, dan protozoa) yang hidup dalam koloni bersama-sama dan bersimbiosis untuk menghasilkan dan membutuhkan energi, karbon, dan nutrien lain (Ozkan, 2011).

\subsection{Analisis Penurunan Konsentrasi COD dan Amonia}

Berdasarkan data yang diperoleh (merujuk pada Lampiran Data), dapat terlihat adanya pengaruh lamanya waktu tinggal hidrolis air limbah dalam proses pengolahan penelitian ini terhadap persentase penyisihan konsentrasi Chemical Oxygen Demand (COD) dan penyisihan konsentrasi Amonia yang terkandung dalam air limbah domestik. Dalam pengolahan air limbah dengan waktu tinggal 12 jam dan rasio media 20\%, kestabilan persentase penyisihan konsentrasi COD lebih kecil dibandingkan waktu tinggal lainnya (yaitu sebesar 62\%) walaupun nilainya sudah berada di bawah Baku Mutu Lingkungan (menurut PerGub DKI Jakarta No. $122 / 2005$, batas maksimum konsentrasi COD adalah $100 \mathrm{mg} / \mathrm{liter}$ ), yaitu dengan rata-rata nilainya 94,3 $\mathrm{mg} /$ liter. Peneliti melakukan penambahan rasio media menjadi $40 \%$ dengan persentase penyisihan konsentrasi COD masing-masing dalam waktu tinggal 12 jam, 16 jam, dan 20 jam adalah 75,7\%; 83,7\%; dan $91,0 \%$. Penambahan tersebut dilakukan dengan melihat bahwa konsentrasiCOD efluen telah memenuhi Baku Mutu Lingkungan tetapi data konsentrasi amonia efluen saat proses pengolahan dijalankan dengan waktu tinggal 12 jam (rasio media 40\%), masih berada di atas Baku Mutu Lingkungan yang ditetapkan (yaitu maksimal $10 \mathrm{mg} / \mathrm{l}$ ) sehingga tujuan penelitian belum tercapai pada parameter Amonia dan perlu adanya penambahan waktu tinggal agar proses lebih efisien dan biomassa lebih mature. Rata-rata nilai konsentrasi COD masing-masing waktu tinggal 12 jam, 16 jam, dan 20 jam tersebut adalah 93,3 mg/liter; 86,4 mg/liter; dan 36,4 mg/liter. Hasil penurunan nilai konsentrasi COD efluen tersebut dipengaruhi salah satunya oleh faktor lamanya ataupun adanya variasi waktu tinggal, sehingga proses pengolahan dan reaksi-reaksi degradasi oleh mikroorganisme lebih efektif dikarenakan menurut Zafarzadeh et al.(2010) proses degradasi polutan dalam air limbah dengan memanfaatkan pertumbuhan mikroorganisme memerlukan waktu tinggal sebagai kesempatan kontak antara mikroorganisme dan lingkungan dalam tempat pengolahan air limbah. Selain itu, hal yang mempengaruhi cepatnya penurunan konsentrasi COD dalam suatu proses pengolahan biologis adalah dengan menambah rasio media. Penelitian ini media bioball hanya ditambahkan pada reaktor aerobik sehingga bila diperhatikan pada penelitian-penelitian 
biofilm lainnya, proses pengolahan akan lebih efektif dengan menambah rasio media pada reaktor anoksik juga, sehingga mikroorganisme yang tumbuh lebih banyak.

Kondisi reaktor saat dijalankan dengan waktu tinggal 12 jam, baik dengan rasio media $20 \%$ maupun $40 \%$, tampak pada reaktor pengendapan biomassa masih mengalami rising sludge dengan gas yang jumlahnya lebih banyak dan biomassa yang mengapung di permukaannya lebih didominasi dengan jenis biomassa berfilamen sehingga gelembung gas lebih mudah terperangkap dalam lembaran-lembaran filamen dan menyebabkan beberapa filamen mengapung ke permukaan reaktor pengendapan. Selain itu, adanya gelembunggelembung gas dalam bak pengendapan tersebut menunjukkan telah berlangsungnya proses denitrifikasi dalam reaktor sebelumnya, sehingga ion nitrit dan nitrat diubah menjadi gas nitrogen (Bjornsdotter et al., 2005).

Berdasarkan hasil pengamatan visual peneliti, biomassa dalam reaktor semakin lebih padat melekat di antara rongga-rongga media, hal ini ditandai/diindikasikan dengan meningkatnya ratarata berat media beserta biomassa yang melekat dalam media. Selain itu, biomassa yang tersuspensi terlihat lebih merata dengan aliran difusi dari bantuan aerator dalam reaktor dan hal tersebut menyebabkan respon terhadap pertumbuhan sel bakteri dalam biofilm di permukaan media, respon ini dapat berupa penurunan maupun kenaikan COD ataupun BOD Fenomena penambahan berat media dan fixed film pada medianya inilah yang dapat meningkatkan optimisme dalam peningkatan efisiensi penyisihan substrat organik (di sini adalah nilai COD reaktor).

Pada umumnya, hasil penelitian terdahulu mengenai karakteristik COD dan BOD dalam suatu proses pengolahan menyatakan bahwa meningkatnya biomassa mikroorganisme akan menyebabkan. turunnya konsentrasi bahan organik pada air limbah. Peningkatan biomassa disebabkan oleh pertumbuhan mikroorganisme dalam air limbah tersebut. Terkadang data yang diperoleh menunjukkan nilai COD reaktor mengalami peningkatan/kenaikan yang dapat disebabkan oleh semakin banyaknya biomassa, baik yang berupa terlekat maupun tersuspensi dalam reaktor, yang terbentuk akibat pertumbuhan sel sehingga bahan organik yang harus didegradasi pun akan bertambah dengan sendirinya. Pada dasarnya, fluktuasi nilai COD berbanding lurus dengan pertambahan sel. Nilai COD naik pada saat jumlah sel cenderung naik (Carolina, 2012). Selain itu, dapat juga disebabkan oleh konsentrasi influen terlalu fluktuatif serta disebabkan oleh kondisi semakin banyak new cell yang lepas menjadi bentuk tersuspensi dan nantinya akan terbawa ke dalam reaktor pengendapan lalu diresirkulasikan kembali, maka bentuk new cell yang seperti inilah yang dapat menaikkan kandungan substrat dan amonia dikarenakan oleh komponen new cell yang terbentuk tersebut terdiri dari unsur $\mathrm{C}, \mathrm{H}, \mathrm{O}, \mathrm{N}, \mathrm{P}$, di mana keseluruhannya akan terjadi akumulasi dan kembali menjadi substrat organik yang harus didegradasi serta menjadi nitrogen yang akan berubah menjadi amonium dalam mediumnya di reaktor. Kondisi inilah yang dapat menyebabkan naik turunnya proses pengolahan dan terutama terlihat pada besar efisiensi penyisihan substrat (mengacu pada nilai COD reaktor) dan amonia.

Sedangkan bila diperhatikan data yang merujuk pada Lampiran Data, persentase penyisihan konsentrasi Amonia, dalam pengolahan dengan waktu tinggal 12 jam, 16 jam, dan 20 jam dan rasio media masing-masing 40\%, berturut-turut adalah sebesar 79,4\%; 90,8\%; dan 92,3\%. Di sini terlihat bahwa dengan semakin lamanya waktu tinggal pengolahan air limbah, maka semakin meningkat persentase penyisihan konsentrasi Amonia yang dapat diasumsikan / diperkirakan penyebabnya oleh waktu tinggal 20 jam pengolahan ini akan stabil dengan kondisi limbah dan mikroorganisme yang lebih mature. Begitu juga dengan nilai rata-rata konsentrasi Amonia efluen telah memenuhi Baku Mutu Lingkungan (menurut PerGub DKI Jakarta No. 122/2005, batas maksimum konsentrasi Amonia adalah $10 \mathrm{mg} /$ liter) berturut-turut 12 jam, 16 jam, dan 20 jam adalah 47,4 mg/liter; 29,9 mg/liter; dan 7,2 mg/liter.

Berdasarkan data yang diperoleh, pengaruh variasi waktu tinggal hidrolis dengan persentase penurunan konsentrasi Amonia dalam proses pengolahan anoksik-aerobik moving bed biofilm pada penelitian ini adalah berbanding lurus dengan persamaan regresi linear yang dicapai, yaitu:

$Y=0,837 X+28,15$ $\left(R^{2}=0,679\right)$

Dari persamaan regresi di atas, variabel $Y$ adalah persentase penyisihan konsentrasi Amonia dan variabel $X$ adalah waktu tinggal hidrolis, hubungan berbanding lurus antara kedua variabel yang diindikasikan oleh positifnya persamaan regresi tersebut. Dalam persamaan tersebut diperoleh nilai $\mathrm{R}^{2}$ adalah 0,679 yang berarti bahwa sekitar $67,9 \%$ variabel persentase penyisihan Amonia dipengaruhi oleh waktu tinggal hidrolis air limbah dalam proses pengolahan ini. Namun, dari data dan grafik (Gambar 2) yang diperoleh tidak mendeskripsikan adanya keterkaitan langsung antara penurunan konsentrasi COD dan konsentrasi Amonia sehingga tidak ada kecenderungan penurunan yang sama, hanya saja keduanya (konsentrasi COD dan Amonia) dipengaruhi oleh laju degradasi substrat yang dilakukan oleh mikroorganisme dalam proses pengolahan dan faktor lingkungan yang mendukung terbentuknya koloni 
mikroorganisme tersebut, sehingga mengakibatkan proses degradasi COD dan Amonia menjadi efekti

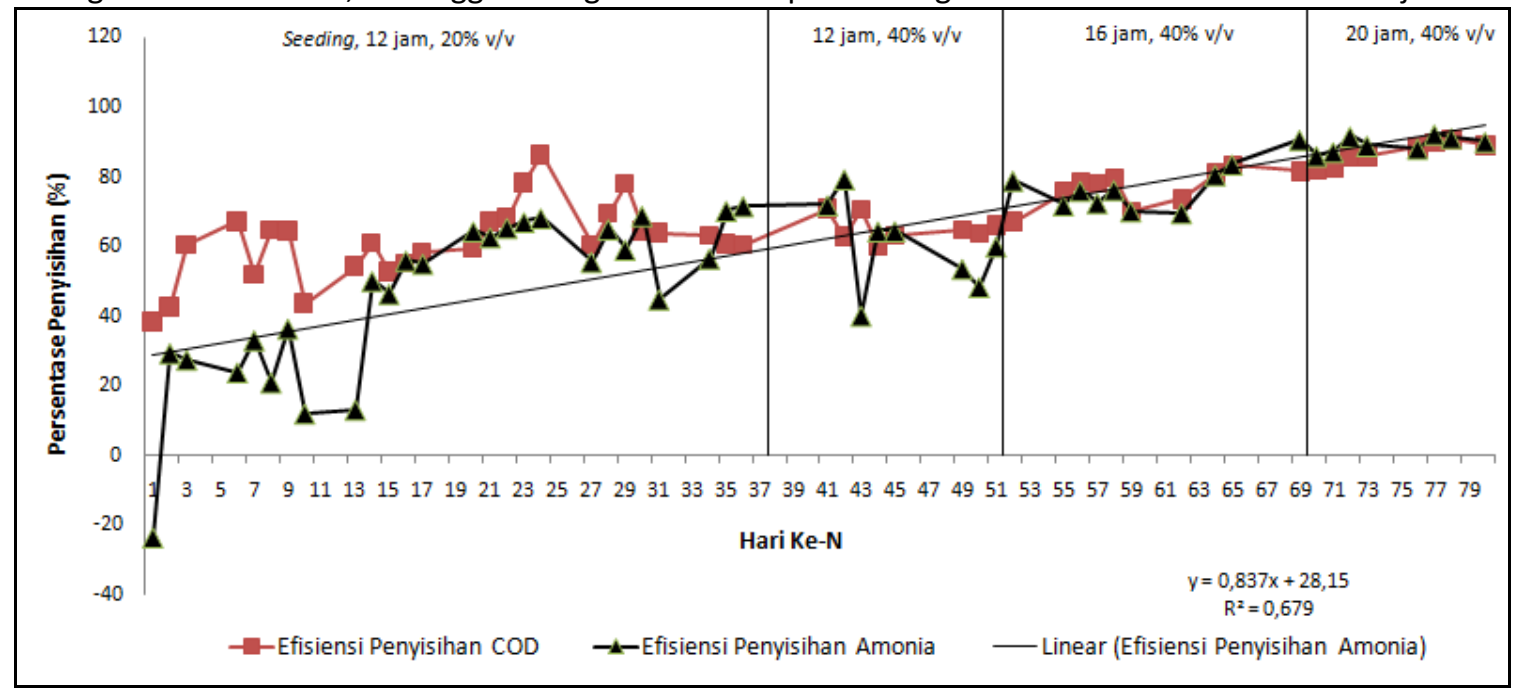

Gambar 2 : Grafik Persentase Penyisihan Konsentrasi COD dan Amonia Terhadap Total Waktu Tinggal Hidrol

\subsection{Evaluasi pH, Temperatur, dan Konsentras Oksigen Terlarut}

Intinya adalah hampir seluruh reaksi dalam suatu proses pengolahan air limbah secara biologis, akan selalu ada perubahan $\mathrm{pH}$, temperatur, dan oksigen terlarut yang ketiganya menjadi hal penting dalam menilai respon mikroorganisme yang teraklimatisasi sebelumnya dalam sistem pengolahan air limbah secara biologis. Sedangkan bedanya, dalam pengolahan air limbah secara kimiawi, perubahan $\mathrm{pH}$ dan temperatur dapat mengindikasikan perubahan reaksi antar senyawa / moleul dalam reaktor pengolahannya. Berikut ini merupakan Gambar 3 yang keduanya menunjukkan adanya interaksi antara mikroorganisme dalam reaktor, senyawa terlarut dalam air limbah yang masuk, dan dengan kata lain, interaksi tersebut menunjukkan aktivitas degradasi mikroorganisme yang diindikasikan melalui perubahan $\mathrm{pH}$ dan temperatur seperti persamaan reaksi yang telah dipaparkan di atas. Untuk air limbah domestik pada penelitian ini tidak begitu terlihat reaksi nitrifikasi/denitrifikasi maupun oksidasi aerobik secara signifikan tetapi dapat diketahui dari berkurangnya substrat (dalam nilai konsentrasi BOD), berkurangnya konsentrasi amonia, dan berkurangnya konsentrasi oksigen terlarut pada titik outlet/keluaran dari reaktor (hal tersebut mengindikasikan adanya konsumsi sejumlah konsentrasi oksigen terlarut dalam reaktor aerobik). $\mathrm{pH}$ dan temperatur menjadi parameter kontrol untuk memastikan dan membuktikan adanya proses nitrifikasi / denitrifikasi dapat berjalan sesuai dengan penelitian terdahulu.

Selain $\mathrm{pH}$ dan temperatur, parameter indikator aktivitas mikroorganisme dan berlangsungnya reaksi antar senyawa dalam medium di reaktor adalah konsentrasi oksigen terlarut. Konsentrasi oksigen terlarut dalam reaktor dibagi menjadi beberapa jenis, yaitu konsentrasi oksigen terlarut aktual (pada proses aerasi) dan konsentrasi oksigen terlarut sisa (pada efluen unit aerasi). Konsentrasi oksigen terlarut aktual yang dimaksudkan di sini adalah sejumlah konsentrasi oksigen terlarut yang sengaja diberikan/diinjeksikan dalam reaktor. Sedangkan konsentrasi oksigen terlarut sisa adalah besar konsentrasi oksigen terlarut yang tercatat dalam efluen reaktor aerasi setelah terjadinya proses pengolahan biologis ataupun dengan kata lain telah terjadi konsumsi oksigen terlarut sebagai adanya aktivitas mikroorganisme di dalamnya. Berikut ini merupakan Gambar 4 yang dapat menunjukkan adanya beda besar konsentrasi oksigen terlarut aktual dan yang tersisa (pada efluen) dalam reaktor.

Berdasarkan Gambar 4 tersebut, dapat dihitung besar persentase penggunaan oksigen terlarut dalam reaktor aerobik, dengan mengkalkulasikan selisih konsentrasi oksigen terlarut aktual dengan oksigen terlarut sisa yang terukur dalam reaktor dan selanjutnya dibagi konsentrasi oksigen terlarut aktual dikali 100\%. Hasilnya adalah terjadi peningkatan persentase penggunaan oksigen terlarut semakin bertambahnya hari operasi dan pengaturan injeksi aerasi ke dalam reaktor (di sini dilakukan penambahan aerasi dari $4 \mathrm{mg} /$ liter hingga 6 $\mathrm{mg} /$ liter dengan menyesuaikan kecenderungan nitrat dan nitrit efluen) dan hal tersebut dilakukan dengan aeration rate antara 4,5 liter/menit hingga 9 liter/menit. Hasil tersebut menjadi pertimbangan penambahan aerasi karena konsentrasi nitrat dan nitrit menjadi salah satu indikasi berlangsungnya nitrifikasi / denitrifikasi dan proses oksidasi aerobik 
serta dapat disimpulkan bahwa dengan bertambahnya konsentrasi oksigen terlarut yang diinjeksikan ke dalam reaktor aerobik, maka semakin besar konsentrasi oksigen terlarut yang dikonsumsi/dipergunakan oleh mikroorganisme dalam reaktor aerobik, hal tersebut mengindikasikan bahwa bila terjadi pengurangan konsentrasi oksigen terlarut dalam reaktor, maka di dalam reaktor telah terjadi proses biologis oleh mikroorganisme, baik oleh jenis bakteri heterotrof maupun autotrof nitrifikasi.

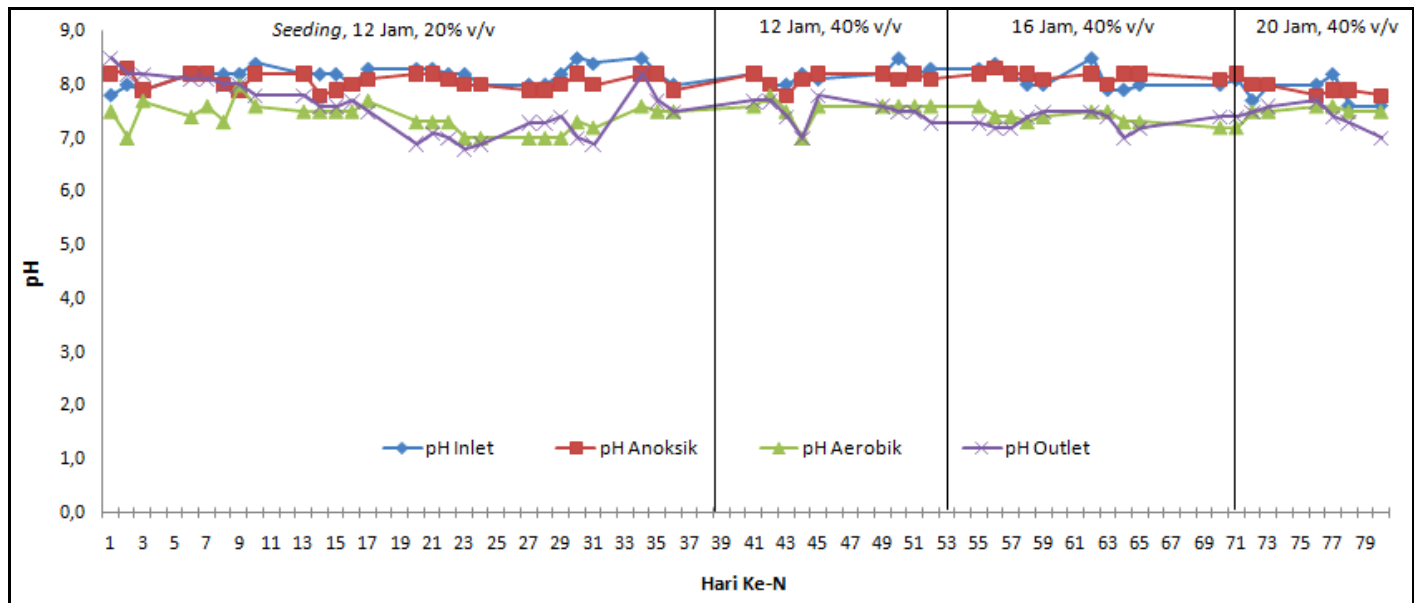

(a)

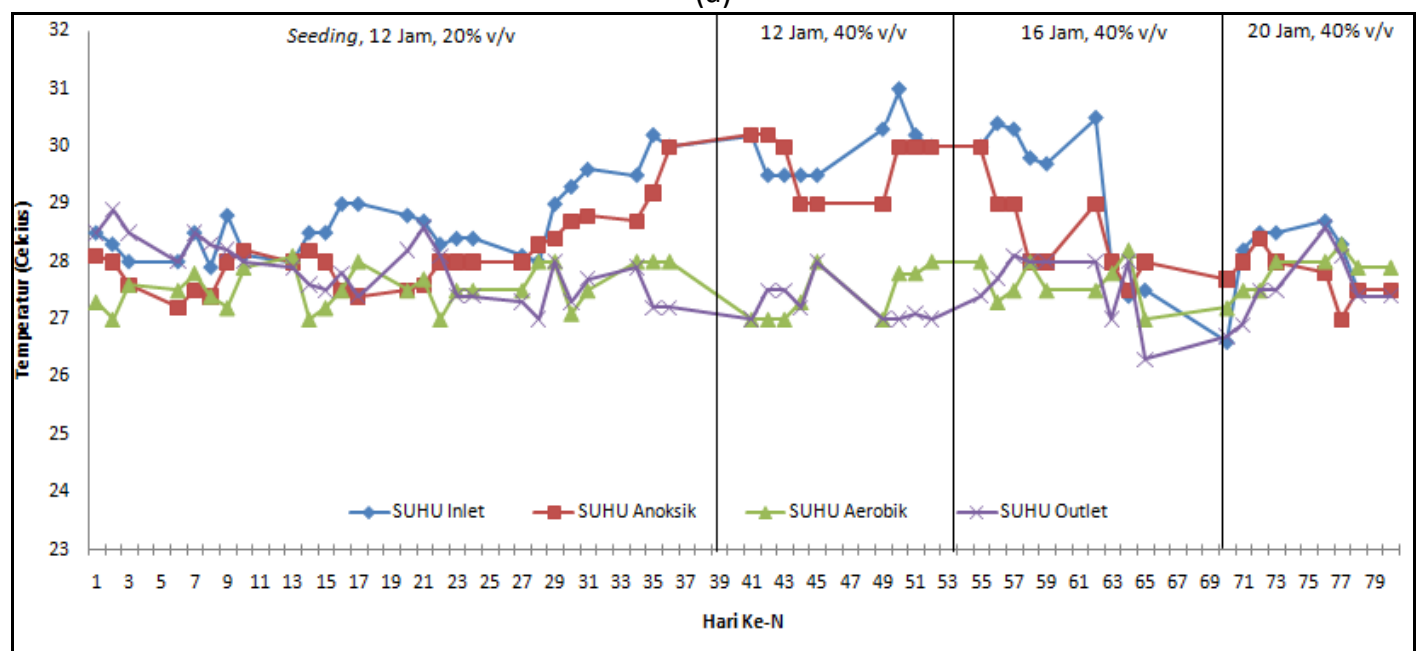

(b)

Gambar 3 : Grafik pH (a) dan Grafik Temperatur Selama Pengolahan Berlangsung (b)

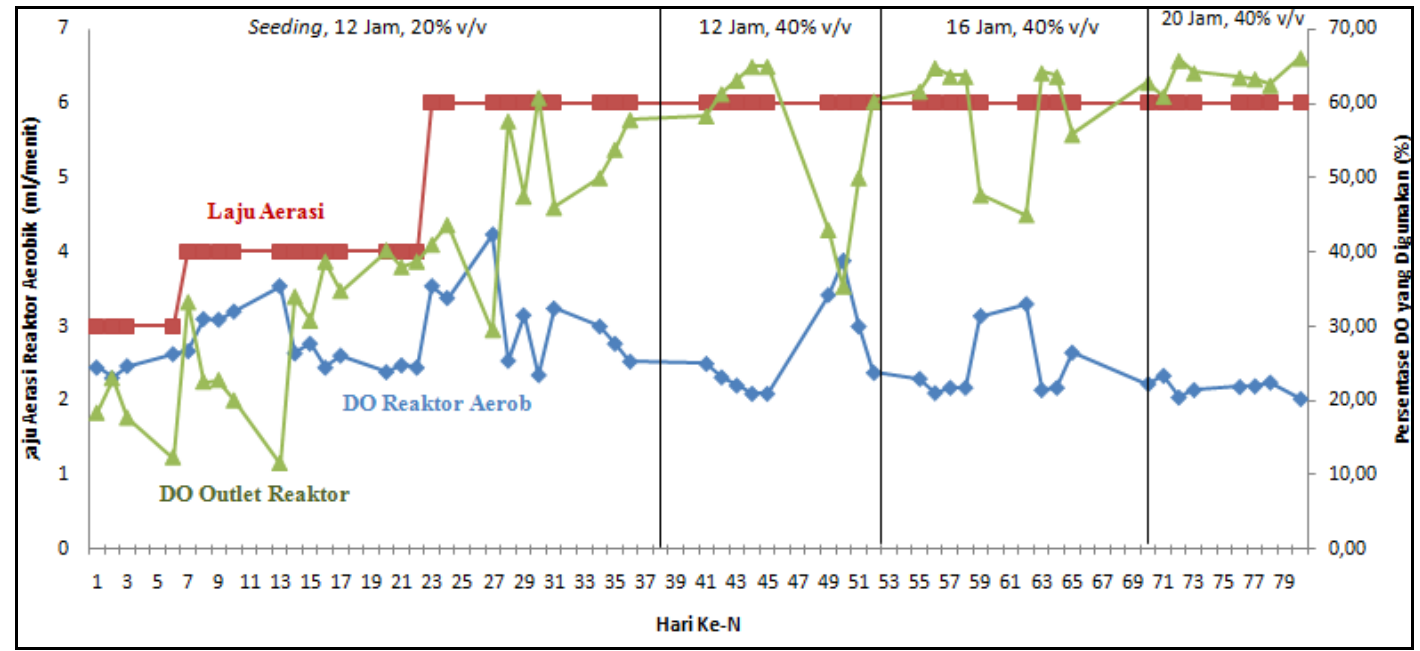


Gambar 4 : Grafik Konsentrasi Oksigen Terlarut dalam Reaktor Aerobik dan Outlet

\section{KESIMPULAN}

Adapun kesimpulan dari penelitian yang dilakukan untuk menghilangkan substrat karbon dan konsentrasi amonia di dalam air limbah domestik dengan mengaplikasikan proses pengolahan biologis anoksik dan aerobik moving bed biofilm reactor, sebagai berikut:

1. Persentase penyisihan konsentrasi Chemical Oxygen Demand (COD) untuk proses pengolahan dengan waktu tinggal hidrolis 12 jam, 16 jam, dan 20 jam dengan masing-masing rasio media $40 \%$ berturut-turut adalah $75,7 \%$; $83,7 \%$; dan $91,0 \%$. Sedangkan penyisihan konsentrasi Amonia berturut-turut adalah 79,4\%; 91,0\%; dan 92,3\%.

2. Pengaruh variasi waktu tinggal hidrolis terhadap persentase penurunan konsentrasi amonia dalam prosesanoxic-aerobic Moving Bed Biofilm adalah dari waktu tinggal hidrolik yang diujikan pada penelitian ini, maka terdapat korelasi bahwa semakin bertambahnya waktu tinggal hidrolik, maka semakin besar efisiensi penurunan senyawa amonia dalam air limbah domestik yang masuk ke dalam proses pengolahan anoksik dan aerobik Moving Bed Biofilm Reactor. Hal tersebut mempunyai hubungan yang berbanding lurus dengan nilai $\mathrm{R}^{2}$ adalah $67,9 \%$ dan persamaan regresi yang diperoleh, yaitu:

$Y=0,837 X+28,15$ $\left(R^{2}=0,679\right)$

3. Waktu tinggal hidrolis yang efektif, hingga konsentrasi COD dan Amonia efluen yang dicapai dapat memenuhi Baku Mutu Lingkungan (menurut PerGub DKI Jakarta No. 122 Tahun 2005), dalam menurunkan substrat karbon dan amonia dengan pengolahan biologis air limbah yang menggunakan anoksik dan aerobik Moving Bed Biofilm Reactor adalah 20 jam dengan rasio media $40 \%$.

\section{DAFTAR PUSTAKA}

1. Canzani, Roberto. (2006). Effect of Oxygen Concentration On Biological Nitrification And Microbial Kinetics In A Cross-flow Membrane Bioreactor (MBR) And Moving Bed Biofilm
Reactor (MBBR) Treating Old Landfill Leachate. Italy, Elsevier Journal Of Membrane Science.

2. Canzani, Roberto. (2006). Effect Of Oxygen Concentration On Biological Nitrification And Microbial Kinetics In A Cross-flow Membrane Bioreactor (MBR) And Moving Bed Biofilm Reactor (MBBR) Treating Old Landfill Leachate. Italy, Elsevier Journal Of Membrane Science.

3. Metcalf and Eddy. (2003). "Wastewater Engineering Treatment, Disposal, and Reuse", Mc Graw-Hill International Edition, New York.

4. Odegraard, Hallvard. (2012). The Influence of Carrier Size And Shape In The Moving Bed Biofilm Process. Norway, Journal Of Anglian Water Service.

5. Ozkan, Okray. (2011). Characterization And Assessment Of A Large-Scale Domestic Advanced Wastewater Treatment Plant In Turkey. Turkey, Environ Mount Assess.

6. Pemerintah Republik Indonesia. Peraturan Gubernur DKI Jakarta No. 122 Tahun 2005 Tentang Pengelolaan Air Limbah Domestik Di Provinsi Daerah Khusus Ibukota Jakarta. Jakarta.

7. Said, Nusa Idaman. (2008). Pengelolaan Air Limbah Domestik Di DKI Jakarta - Tinjauan Permasalahan, Strategi, dan Teknologi Pengolahan. BPPT. Jakarta.

8. Sarwanto, Setyo. (1995). Nitrifikasi pada Reaktor Fluidisasi secara Biologis untuk Pengolahan Air Buangan Industri Tahu. Depok.

9. Sheng, Chen. (2007). Simultaneous Removal of COD And Ammonium From Landfill Leachate Usingn An Anaerobic-Aerobic Moving Bed Biofilm Reactor System. Korea, Elsevier Journal of Waste Management.

10. Sya'bani, Muhammad Rizki. (2012). "Pengaruh Variasi Waktu Tinggal Hidraulik terhadap Efisiensi Penyisihan Amoniak dalam Air Limbah Domestik pada Sistem Moving Bed Biofilm Reactor", Universitas Mulawarman, Samarinda.

11. Zafarzadeh, A. (2011). Effects Of Dissolved Oxygen And Chemical Oxygen Demand To Nitrogen Ratios On The Partial Nitrification/ Denitrification Process In Moving Bed Biofilm Reactors. Iran. Journal Of Biotechnology.

12. Zafarzadeh, A., Bina, Nikaeen et.al. (2010). Performance of Moving Bed Biofilm Reactors for Biological Nitrogen Comounds Removal from Wastewater by Partial NitrificationDenitrification Process, Isfahan, Iran. 
Tabel 1 : Konsentrasi $\mathrm{BOD}_{5}, \mathrm{COD}$, dan Amonia Kondisi Seeding

\begin{tabular}{|c|c|c|c|c|c|c|c|c|c|}
\hline \multirow{2}{*}{ Hari Ke-N } & \multicolumn{3}{|c|}{$\left[\mathrm{BOD}_{5}\right] \mathrm{mg} / \mathrm{l}$} & \multicolumn{3}{|c|}{$[\mathrm{COD}] \mathrm{mg} / \mathrm{l}$} & \multicolumn{3}{|c|}{$[\mathrm{NH} 4-\mathrm{N}] \mathrm{mg} / \mathrm{l}$} \\
\hline & Inlet & Outlet & Ef. Rem \% & Inlet & Outlet & Ef. Rem \% & Inlet & Outlet & Ef. Rem \% \\
\hline \multicolumn{10}{|c|}{ Operasi Seeding HRT 12 Jam dan Rasio Media 20\% } \\
\hline 1 & & & & 115 & 71 & 38,26 & 39,61 & 48,89 & $-23,43$ \\
\hline 2 & & & & 110 & 63 & 42,73 & 68,43 & 48,23 & 29,52 \\
\hline 3 & 47,3 & 33,6 & 29 & 132 & 52 & 60,61 & 65,2 & 47,17 & 27,65 \\
\hline 6 & & & & 125 & 41 & 67,28 & 98,03 & 74,52 & 23,98 \\
\hline 7 & & & & 115 & 55 & 51,97 & 138,07 & 92,22 & 33,21 \\
\hline 8 & 55,8 & 32,6 & 41,6 & 129 & 45 & 64,98 & 86,74 & 68,45 & 21,09 \\
\hline 9 & & & & 128 & 45 & 64,73 & 75,52 & 47,93 & 36,53 \\
\hline 10 & & & & 135 & 76 & 43,62 & 68,48 & 60,17 & 12,13 \\
\hline 13 & 54,9 & 35,4 & 35,5 & 126 & 57,43 & 54,42 & 65,85 & 57,12 & 13,26 \\
\hline 14 & & & & 121 & 47 & 61,09 & 66,98 & 33,35 & 50,21 \\
\hline 15 & & & & 145 & 68,5 & 52,86 & 66,28 & 35,44 & 46,53 \\
\hline 16 & & & & 145 & 65 & 55,17 & 74,55 & 32,76 & 56,06 \\
\hline 17 & 76,4 & 56,3 & 26,3 & 155 & 64,3 & 58,52 & 68,96 & 30,94 & 55,13 \\
\hline 20 & & & & 135 & 54,2 & 59,79 & 72,66 & 25,82 & 64,46 \\
\hline 21 & & & & 144 & 47 & 67,41 & 61,34 & 22,88 & 62,7 \\
\hline 22 & 83,5 & 35,1 & 58 & 143 & 45,27 & 68,34 & 68,12 & 23,55 & 65,43 \\
\hline 23 & & & & 196 & 42,15 & 78,49 & 67,37 & 22,17 & 67,09 \\
\hline 24 & & & & 188 & 25,47 & 86,45 & 67,37 & 21,41 & 68,22 \\
\hline 27 & 85,7 & 36,9 & 56,9 & 167 & 66 & 60,48 & 58,94 & 26,09 & 55,73 \\
\hline 28 & & & & 179 & 54 & 69,83 & 58,53 & 20,47 & 65,03 \\
\hline 29 & & & & 189 & 41 & 78,31 & 48,21 & 19,67 & 59,2 \\
\hline 30 & & & & 195 & 69 & 64,62 & 62,72 & 19,48 & 68,94 \\
\hline 31 & 85,4 & 27,6 & 67,7 & 200 & 72 & 64 & 59,22 & 32,62 & 44,92 \\
\hline 34 & & & & 242 & 89 & 63,22 & 53,4 & 23,14 & 56,67 \\
\hline 35 & & & & 250 & 98 & 60,8 & 60,28 & 17,89 & 70,32 \\
\hline 36 & 158,4 & 35,5 & 77,6 & 243 & 96 & 74,52 & 69,38 & 19,62 & 71,72 \\
\hline Minimum & 47,3 & 27,6 & 26,3 & 110 & 25,47 & 38,26 & 39,61 & 17,89 & $-23,43$ \\
\hline Rata-rata & 80,9 & 36,6 & 49,1 & 160 & 59,59 & 62,02 & 68,86 & 37,38 & 46,24 \\
\hline Maksimum & 158,4 & 56,3 & 77,6 & 250 & 98 & 86,45 & 138,07 & 92,22 & 71,72 \\
\hline
\end{tabular}


Tabel 2 : Konsentrasi BOD ${ }_{5}$, COD, dan Amonia HRT 12 Jam (Rasio Media 40\%)

\begin{tabular}{|c|c|c|c|c|c|c|c|c|c|}
\hline \multirow{2}{*}{ Hari Ke-N } & \multicolumn{3}{|c|}{$\left[\mathrm{BOD}_{5}\right] \mathrm{mg} / \mathrm{l}$} & \multicolumn{3}{|c|}{$[\mathrm{COD}] \mathrm{mg} / \mathrm{l}$} & \multicolumn{3}{|c|}{$[\mathrm{NH} 4-\mathrm{N}] \mathrm{mg} / \mathrm{l}$} \\
\hline & Inlet & Outlet & Ef. Rem \% & Inlet & Outlet & Ef. Rem \% & Inlet & Outlet & Ef. Rem \% \\
\hline \multicolumn{10}{|c|}{ Operasi HRT 12 Jam dan Rasio Media 40\% } \\
\hline 41 & 165 & 67,2 & 59,27 & 330 & 96 & 70,91 & 76,42 & 21,44 & 71,94 \\
\hline 42 & 154,8 & 76,4 & 50,65 & 397 & 147 & 62,97 & 74,3 & 15,32 & 79,38 \\
\hline 43 & 194,4 & 52,3 & 73,1 & 324 & 95 & 70,68 & 73,42 & 43,87 & 40,25 \\
\hline 44 & 157,6 & 37,4 & 76,27 & 209 & 83 & 60,29 & 226,51 & 80,46 & 64,48 \\
\hline 45 & 143,5 & 43,6 & 69,62 & 242 & 89 & 63,22 & 230 & 81,65 & 64,5 \\
\hline 49 & 130,5 & 37,9 & 70,96 & 225 & 79 & 63,86 & 128,09 & 59,34 & 53,67 \\
\hline 50 & 137 & 40,4 & 70,51 & 245,32 & 83,09 & 66,13 & 128,09 & 66,02 & 48,46 \\
\hline 51 & 154,6 & 48,2 & 68,82 & 247,69 & 81,23 & 67,2 & 98,05 & 39,12 & 60,1 \\
\hline 52 & 156 & 48,7 & 68,78 & 356,79 & 86,57 & 75,74 & 93,25 & 19,56 & 79,02 \\
\hline Minimum & 130,5 & 37,4 & 50,65 & 209 & 79 & 60,29 & 73,42 & 15,32 & 40,25 \\
\hline Rata-rata & 154,8 & 50,2 & 67,55 & 286,31 & 93,32 & 66,78 & 125,35 & 47,42 & 62,42 \\
\hline Maksimum & 194,4 & 76,4 & 76,27 & 397 & 147 & 75,74 & 230 & 81,65 & 79,38 \\
\hline \multicolumn{10}{|c|}{ Operasi HRT 16 Jam dan Rasio Media 40\% } \\
\hline 55 & 142,7 & 34,6 & 75,75 & 359,25 & 76,45 & 78,72 & 98,93 & 27,77 & 71,93 \\
\hline 56 & 165,3 & 38,2 & 76,89 & 343,33 & 74,38 & 78,34 & 95,32 & 22,8 & 76,08 \\
\hline 57 & 188,8 & 22,3 & 88,19 & 320,47 & 64,32 & 79,93 & 97,55 & 26,75 & 72,58 \\
\hline 58 & 160,2 & 27,7 & 82,71 & 425,3 & 126,15 & 70,34 & 98,43 & 23,33 & 76,3 \\
\hline 59 & 255,2 & 56,8 & 77,74 & 423,95 & 111,07 & 73,8 & 98,67 & 29,44 & 70,16 \\
\hline 62 & 258,6 & 53,3 & 79,39 & 414,22 & 106,27 & 74,34 & 98,5 & 29,86 & 69,69 \\
\hline 64 & 277,5 & 44,6 & 83,93 & 406,02 & 76,84 & 81,07 & 96,53 & 18,75 & 80,58 \\
\hline 65 & 263,9 & 30,7 & 88,37 & 401,62 & 65,32 & 83,74 & 94,12 & 15,43 & 83,61 \\
\hline 69 & 224,9 & 29,4 & 86,93 & 420,85 & 76,94 & 81,72 & 94,12 & 8,82 & 90,77 \\
\hline Minimum & 142,7 & 22,3 & 75,8 & 320,5 & 64,3 & 70,3 & 94,1 & 8,8 & 69,7 \\
\hline Rata-rata & 215,2 & 37,5 & 82,21 & 390,56 & 86,42 & 78,00 & 96,91 & 22,55 & 76,86 \\
\hline Maksimum & 277,5 & 56,8 & 88,4 & 425,3 & 126,2 & 83,7 & 98,9 & 29,9 & 90,8 \\
\hline \multicolumn{10}{|c|}{ Operasi HRT 20 Jam dan Rasio Media 40\% } \\
\hline 70 & 165,4 & 35,4 & 78,6 & 378,1 & 67,15 & 82,24 & 96,48 & 13,43 & 86,08 \\
\hline 71 & 216,2 & 32,7 & 84,88 & 400,2 & 68,69 & 82,84 & 96,21 & 12,3 & 87,22 \\
\hline 72 & 212,8 & 24,3 & 88,58 & 395,19 & 55,23 & 86,02 & 98,52 & 8,21 & 91,67 \\
\hline 73 & 206 & 27,8 & 86,5 & 412,32 & 57,32 & 86,1 & 95,82 & 10,5 & 89,04 \\
\hline 76 & 183,2 & 22,8 & 87,55 & 358,76 & 40,89 & 88,6 & 92,31 & 10,85 & 88,25 \\
\hline 77 & 215,8 & 17,3 & 91,98 & 387,25 & 38,33 & 90,1 & 92,3 & 7,15 & 92,25 \\
\hline 78 & 260,5 & 19,2 & 92,63 & 403,15 & 36,42 & 90,97 & 93,28 & 8,2 & 91,21 \\
\hline 80 & 174,2 & 20,3 & 88,35 & 355,49 & 37,89 & 89,34 & 92,47 & 9,13 & 90,13 \\
\hline Minimum & 165,4 & 17,3 & 78,6 & 355,49 & 36,42 & 82,24 & 92,3 & 7,15 & 86,08 \\
\hline Rata-rata & 204,3 & 25,0 & 87,38 & 386,31 & 50,24 & 87,03 & 94,67 & 9,97 & 89,48 \\
\hline Maksimum & 260,5 & 35,4 & 92,63 & 412,32 & 68,69 & 90,97 & 98,52 & 13,43 & 92,25 \\
\hline
\end{tabular}

